\title{
INSTRUMEN REAL TIME ROCK RESISTIVITY METER UNTUK MENGUKUR RESISTIVITAS DAN MEMONITOR SIFAT KELISTRIKAN SAMPEL BATUAN
}

\author{
Ida Bagus Suananda Yogi, Rian Pangestu, I Gede Boy Darmawan, Karyanto \\ Program Studi Tenik Geofisika, Fakultas Teknik Universitas Lampung \\ e-mail : suananda.yogi@eng.unila.ac.id
}

\begin{abstract}
Abstrak. Resistivitas adalah salah satu sifat fisis batuan yang banyak dimanfaatkan dalam berbagai bidang seperti eksplorasi sumber daya, geoteknik, teknik lingkungan, dan mitigasi bencana. Nilai resistivitas didapat dengan menggunakan pengukuran geolistrik, MT, ataupun AMT di permukaan. Nilai yang diukur di lapangan dapat divalidasi dengan membandingkan nilai resistivitas sampel batuan secara langsung. Oleh sebab itu, dibuatlah instrumen Real Time Rock Resistivity Meter yang dirancang untuk dapat mengukur nilai resistivitas batuan secara otomatis dan langsung (real time). Proses monitor dan pengukuran dilakuan di komputer dengan memanfaatkan microcontroller Arduino. Validasi alat dilakukan dengan menggunakan resistor sebesar $1 \mathrm{k} \Omega, 10 \mathrm{k} \Omega, 100 \mathrm{k} \Omega$, dan $1 \mathrm{M} \Omega$ dengan eror pengukuran kurang dari 2.2 \%. Sampel batuan yang diukur berupa batuan Tuf dan batuan beku. Hasil pengukuran menghasilkan dua kecendrungan nilai, yaitu saat hasil pengukuran polaritas positif dan negatif. Perbedaan ini terjadi karena adanya energi listrik yang tersimpan di dalam batuan. Dari analisis yang dilakukan, nilai resistivitas batuan dihitung dari rata-rata kedua polaritas. Batuan tuf memiliki nilai resistivitas sebesar $12,6 \mathrm{k} \Omega \mathrm{m}$ dan batuan beku sebesar $262 \mathrm{k} \Omega \mathrm{m}$. Tuf basah memiliki nilai resistivitas 89,7 $\Omega \mathrm{m}$ dan berangsur naik hingga 10,1 k $\Omega \mathrm{m}$ selama 9 hari. Nilai yang bervariasi ini terjadi karena batuan tuf memiliki rekahan yang dapat menyimpan dan cepat melepas air. Dengan kemampuan ini, instrumen Real Time Rock Resistivity Meter dapat digunakan untuk validasi atau bahkan menghasilkan referensi nilai reisistivitas formasi batuan di sekitar kita.
\end{abstract}

Kata Kunci: Resistivitas; Arduino; Geolistrik; Instrumentasi

\begin{abstract}
Resistivity is one of the physical properties of rock that is widely used in various fields such as resource exploration, disaster mitigation, geotechnical, and environmental engineering. The resistivity value is obtained using geoelectric, MT, or AMT measurements on the surface. The values measured in the field can be validated by comparing the resistivity values of rock samples directly. Therefore, the Real Time Rock Resistivity Meter instrument was created which is designed to measure the resistivity value of rocks automatically and in real time. The monitoring and measurement process is carried out on a computer using the Arduino microcontroller. Instrument validation is carried out using resistors of $1 \mathrm{k} \Omega, 10 \mathrm{k} \Omega, 100$ $k \Omega$, and $1 \mathrm{M} \Omega$ with a measurement error of less than $2.2 \%$. Rock samples measured were Tuff and igneous rocks. The measurement results produce two value trends, namely when the measurement results are positive and negative polarity. This difference occurs because of the electrical energy stored in the rock. From the analysis carried out, the rock resistivity value is calculated from the average of the two polarity. The tuff rock has a resistivity value of $12.6 \mathrm{k} \Omega \mathrm{m}$ and igneous rock of $262 \mathrm{k} \Omega \mathrm{m}$. Wet tuff has a resistivity value of $89.7 \Omega \mathrm{m}$ and gradually rises to $10.1 \mathrm{k} \Omega \mathrm{m}$ for 9 days. This varying value occurs because the tuff rock has fractures that can store and quickly release water. With this capability, the Real Time Rock Resistivity Meter instrument can be used for validation or even to generate a reference value for the resistivity of rock formations around us.
\end{abstract}

Keywords: Resistivity; Arduino; Geoelectric; Instrument

\section{PENDAHULUAN}

Geofisika mempelajari bumi dari sifat fisis batuan, salah satunya sifat kelistrikan berupa resistivitas batuan. Resistivitas mengindikasikan kesukaran sebuah batuan untuk melewatkan arus listrik. Nilai ini dipengaruhi oleh faktor-faktor internal dari batuan seperti, kandungan air, porositas, kandungan mineral, sifat matriks batuan, dsb. Penggunaan resistivitas di bidang keteknikan bangunan salah satunya untuk memetakan keberadaan retakan bendungan. Raji dan Adedoyin, 2020 melakukan survey resistivitas permukaan untuk mendeteksi kerusakan bendungan. Dari penelitian tersebut diketahui bahwa nilai resistivitas batuan yang tersturasi air kurang dari $100 \Omega \mathrm{m}$, 
batuan beku yang dominan di area tersebut memiliki nilai resistivitas $500 \Omega \mathrm{m}$, Sementara itu, fondasi bangunan bendungan yang diisi oleh batuan granit memiliki reisitivitas sangat besar $(>12000$ $\Omega m)$. Hal menarik yang didapat dari penelitian ini adalah ditemukannya rongga di fondasi bangunan yang disisipi oleh air dan memiliki nilai resistivitas sangat rendah $(<10 \Omega \mathrm{m})$.

Di bidang lingkungan, penentuan resitivitas dapat membantu peneliti untuk mengetahui penyebaran limbah cair pada media padat (Karyanto, 2007). Penelitian lain juga dilakukan untuk mendeliniasi akuifer air tanah di cekungan sedimen (Aluko dkk., 2017). Pada penelitian ini ditemukan bahwa batuan pasir yang tersaturasi air memiliki nilai resistivitas $13,7 \Omega \mathrm{m}$ hingga $253 \Omega \mathrm{m}$. Mengacu pada nilai resistivitas permukaan dan data sampel diketahui memiliki permeabilitas $46 \mathrm{l} / \mathrm{s}$ hingga $48 \mathrm{l} / \mathrm{s}$. Oleh karena itu, batuan ini yang dianggap sebagai akuifer yang produktif.

Penentuan bidang gelincir yang berpotensi longsor juga dapat dilakukan dengan menggunakan nilai resistivitas batuan. Potensi ini didapat dari menghubungkan parameter geoteknik batuan seperti indeks plastisitas dengan resistivitas batuan (Mohammed dkk., 2019).

Pengukuran resistivitas dapat dilakukan dengan cara mengukur dari permukaan dengan metode Wenner, Schlumberger atau Dipole-dipole, atau dengan secara langsung mengukur sampel batuan. Pengukuran yang biasa dilakukan adalah pengukuran dipermukaan yang dapat mengetahui nilai tahanan jenis di bawah permukaan. Nilai tahanan jenis ini dicocokkan dengan daftar nilai resistivitas batuan di seluruh dunia yang telah dipublikasikan secara global. Permasalahan yang ditemukan adalah nilai di daftar resistivitas tersebut terlalu luas dan saling tumpang tindih, sehingga diperlukan pengukuran langsung terhadap batuan yang kita miliki (Giao dkk., 2003). Dengan mampu mengukur nilai resistvitas batuan secara langsung maka kita bisa mendapatkan sifat kelistrikan yang unik dari geologi lampung, tanpa perlu mengacu kepada nilai global.
Oleh karena itu, perlu dibuat sebuah instrumen pengukur nilai resistivitas yang mampu mengkuatisasi nilai reisistivitas batuan. Desain dan mekanisme instrumen ini perlu dipelajari dan dipersiapkan sehingga alat yang digunakan dapat menjadi alat yang tepat guna. Sebelumnya desain isntrumen ini telah dikembangkan oleh beberapa peneliti. Desain pada Telford dkk., 1990 menggunakan sistem empat elektroda dan arus AC. Giao dkk., 2003 telah mengembangan instrumen untuk mengukur sampel batuan lempung dengan menggunakan empat elektroda DC. Instrumen pengukuran dengan empat elektroda juga dikembangkan oleh Caselle dkk., 2019 yang digunakan untuk mengukur bautan gipsum. Instrumen dengan empat elektroda cocok digunakan untuk batuan lunak.

Berdasarkan permasalahan tersebut penelitian ini dilakukan untuk merancang dan membuat sebuah alat pengukur resistivitas batuan secara langsung. Alat ini selanjutnya disebut sebagai Real Time Rock Resistivity Meter. Instrumen ini menggunakan arus DC yang sesuai dengan kondisi pengukuran di lapangan, yaitu menggunakan arus DC. Selain itu, instrumen ini menggunakan dua elektroda diujung batuan yang dapat digunakan untuk mengukur sampel batuan lunak dan keras. Penelitian ini diharapkan dapat menghasilkan instrumen pengukuran resistivitas batuan secara langsung. Instrumen ini kemudian akan digunakan sebagai sarana utama dalam mengkarakterisasi sifat kelistrikan formasi batuan yang ada, khususnya di Lampung.

\section{TEORI RESISTIVITAS}

Resistansi adalah kuantitas kelistrikan yang menggambarkan sebuah benda atau material menahan arus listrik yang mengalir di dalamnya. Nilai resistansi (R) memiliki satuan ohm $(\Omega)$. Secara matematis, resistansi dapat disebut sebagai perbandingan antara beda potensial dan arus yang dihasilkan. Jika kita menerapkan perbedaan potensial yang sama antara ujung batang tembaga dan kaca yang serupa secara geometris, akan menghasilkan arus yang sangat berbeda. 
Karakteristiknya konduktor yang memengaruhiadalah hambatan atau resistansi listrik dari batang. Dengan menentukan resistensi antara dua titik konduktor serta menerapkan perbedaan potensial (V) antara titik-titik tersebut dan mengukur arus (I) yang dihasilkan. Hambatan (R) kemudian dapat ditulis

$$
R=\frac{V}{I}
$$

Resistansi konduktor tergantung pada cara pemberian beda potensial yang akan diterapkan. Gambar 1, misalnya, menunjukkan perbedaan potensial yang diberikan dalam dua cara berbeda pada konduktor yang sama. Jika aliran arus listrik dimasukkan ke dalam konduktor, maka nilai resistansi di kedua kasus akan berbeda. Kecuali dinyatakan lain, maka beda potensial yang diberikan sebagaimana diterapkan pada Gambar 1 (Halliday dkk., 2011).

Resistansi (R) adalah sifat dari objek, sedangkan resistivitas ( $\rho$ ) adalah sifat dari material, jadi berapapun ukuran dari objek nilai resistivitas akan sama. Sama halnya dengan massa jenis pada sebuah material. Resistivitas atau yang juga dikenal sebagai tahanan jenis ( $\rho)$ memiliki satuan ( $\Omega . m)$.

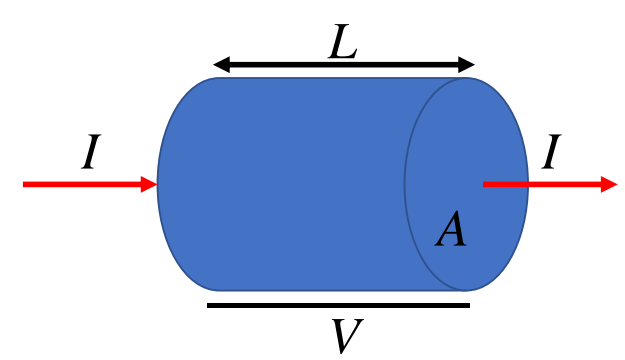

Gambar 2. Model konduktor berbentuk tabung

Nilai resistansi sebuah tabung homogen isotropis seperti pada Gambar 2 dapat dihitung dengan persamaan.

$$
R=\rho \frac{L}{A}
$$

dengan $\mathrm{L}$ adalah panjang, A merupakan luas penampang tempat kontak antara elektroda dan benda, dan $\rho$ adalah resistivitas dari material penyusun benda tersebut.

Sementara itu, jika kita subtitusikan persamaan 1 ke dalam persamaan 2 maka dapat dihitung nilai resistansi sebuah benda. Jika diketahui arus yang mengalir, beda tegangan yang terukur, luas penampang, dan panjang benda maka nilai resistivitas dihitung dengan persamaan

$$
\rho=\frac{V A}{I L}
$$

Kita dapat menggunakan resistivitas untuk mengidentifikasi jenis batuan, kandungan air, ataupun porositas batuan, namun berdasarkan data resistivitas empiris yang diukur di batuan dan material di seluruh dunia dapat dilihat pada Gambar 3 (Dentith \& Mudge, 2014), hal ini tidak mudah dilakukan. Pada gambar ini terlihat variasi resistivitas dalam skala log yang cukup lebar dan saling beririsan antar batuan. Hal ini mengindikasikan secara umum cukup susah mendefinisikan batuan berdasarkan nilai resistivitas data permukaan yang tepat, tanpa melakukan pengukuran resitivitas batuan sampel. Hal yang mungkin dilakukan adalah mengambil sampel sebanyak mungkin dan secara langsung menghitung resistivitas batuan tersebut. Semakin banyak data resistivitas yang tersedia, maka studi di masa mendatang akan lebih mudah dalam menentukan jenis batuan berdasarkan resistivitas. Hal ini sudah dilakukan oleh Caselle dkk., 2019 yang melakukan pengukuran langsung nilai resistivitas gypsum dari sampel yang diambil di lokasi penelitian. 


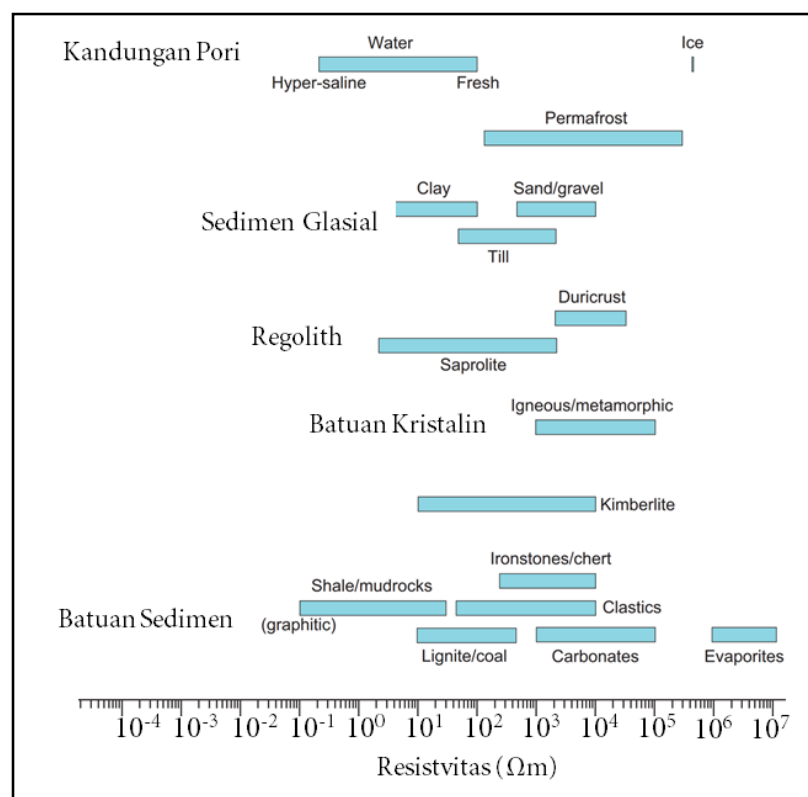

Gambar 3. Tabel resistivitas kompilasi data dari berbagai tempat di dunia.

\section{METODOLOGI}

Di alam ada berbagai jenis batuan, dari berbagai jenis itu banyak faktor yang memengaruhiresistivitas batuan. Untuk memperkirakan respon resistivitas terhadap nilai tegangan dan arus pertama-tama dihitung nilai resistansi yang mungkin. Resistansi dapat dihitung berdasarkan nilai resistivitas batuan dan dimensi. Berdasarkan tabel resistivitas pada Gambar 3 dan memperkirakan batuan memiliki dimensi berbentuk tabung dengan diameter $2.5 \mathrm{~cm}$ dan ketinggian 2.5 $\mathrm{cm}$. Dipilih batuan yang ada di daerah Lampung, yaitu batuan pasir, batuan beku, dan batuan tuf yang telah termetamorfkan. Rentang resistivitas yang digunakan berdasarkan tabel di atas adalah

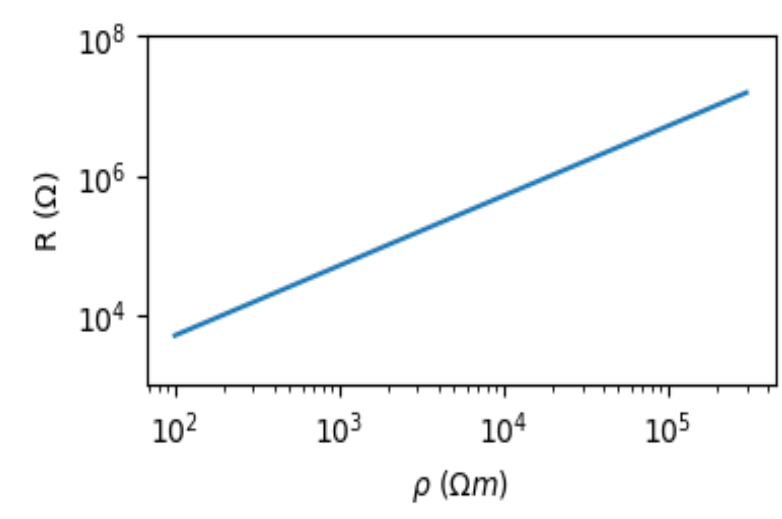

Gambar 4. Kurva resistivitas dibanding resistansi hasil simulasi. dari $100 \Omega \mathrm{m}$ hingga $300000 \Omega \mathrm{m}$. Menggunakan simulasi berdasarkan rumus resistivitas didapat nilai resistansi sesuai Gambar 4.

Nilai $R$ terkecil adalah $5 \times 10^{3} \Omega$ dan nilai terbesar adalah $15 \times 10^{6} \Omega$. Dengan bekal nilai resistansi ini dihitung nilai arus jika diberikan nilai voltase tertentu. Karena besarnya nilai resistansi yang mungkin diukur, dipilih sebuah sumber listrik dengan voltase yang besar. Pada penelitian ini digunakan sumber tegangan yang dapat menghasilkan voltase maksimum $80 \mathrm{~V}$.

Dari perhitungan didapat nilai arus terkecil atau saat resistivitas batuan terbesar adalah 5,5 uA, dan nilai arus terbesar atau saat resistivitas batuan terkecil adalah $16 \mathrm{~mA}$ (Gambar 5).

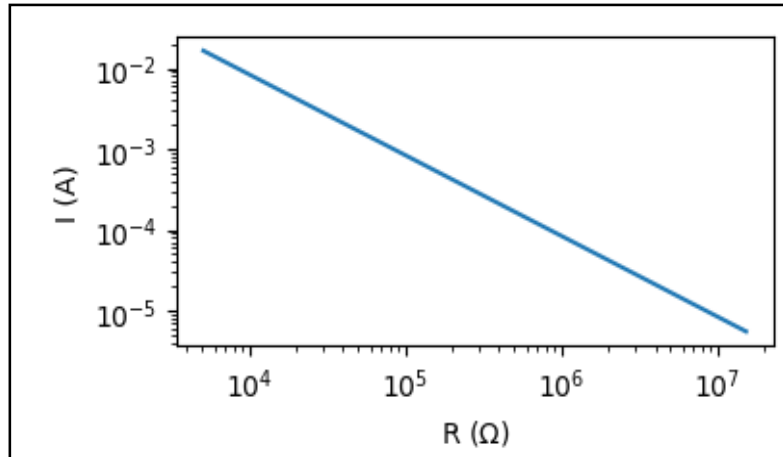

Gambar 5. Kurva resistivitas dibanding arus listrik hasil simulasi.

Metode yang digunakan untuk mengukur arus adalah dengan melakukan pembagian tegangan antara tegangan sampel dan tegangan sebuah resistor sesuai dengan Gambar 6. R adalah sampel batuan yang diukur, $R_{1}$ adalah resistor batuan yang digunakan untuk membagi tegangan, dan $\mathrm{V}_{\text {in }}$ adalah

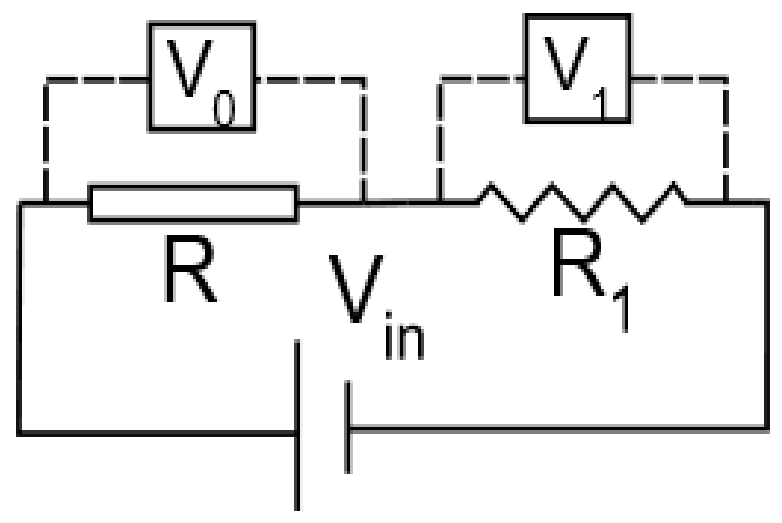

Gambar 6. Skema pembagi tegangan 
sumber tegangan. Berdasarkan hukum pertama Ampere arus dan nilai $\mathrm{R}$ dapat dihitung dilakukan dengan persamaan 3

$$
\begin{aligned}
& I=V_{1} / R_{1} \\
& R=V_{0} / I
\end{aligned}
$$

Pada skema ini hasil $\mathrm{V}_{1}$ yang terukur bervariasi dari $0.005 \mathrm{~V}$ hingga $79.92 \mathrm{~V}$. Karena ingin dibuat sebuah instrument pengukuran digital, maka voltase yang diukur harus mampu terakomodasi oleh toleransi dari Arduino, yaitu 5 V. Berkaca pada hal tersebut dibuat sebuah mekanisme pembagi tegangan orde dua, sebagai berikut

$$
\begin{aligned}
& I=V_{3} \frac{R_{1}+\left(R_{2}+R_{3}\right)}{R_{1} R_{3}} \\
& R=V_{0} / I
\end{aligned}
$$

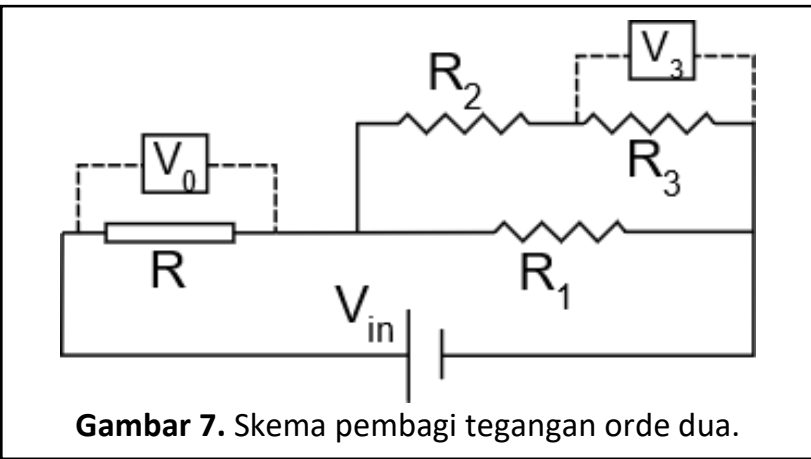

Dengan persamaan di atas dicoba simulasi pengukura $V_{1}$ nilai $R_{p}$ yang bervariasi, yaitu $1 \mathrm{k} \Omega, 10$ $k \Omega$, dan $100 k \Omega$. Simulasi ini dilakukan karena Arduino memiliki ADC ADS1115 sebesar 15-bit atau mampu mengukur nilai $V$ terkecil sebesar 0.1875 $\mathrm{mV}$ atau $0.0001875 \mathrm{~V}$.

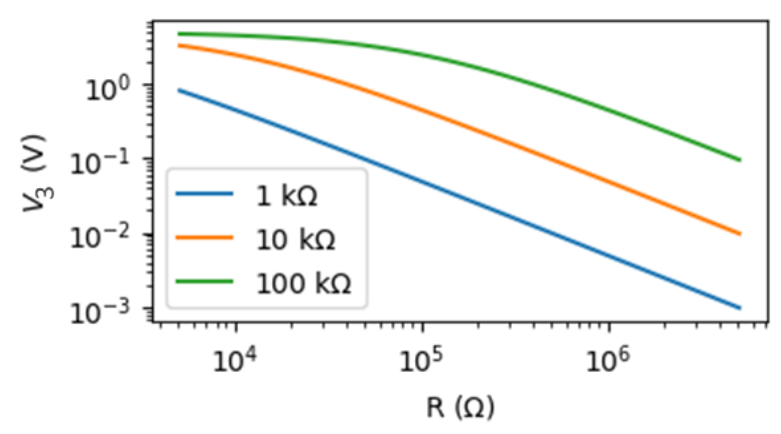

Gambar 8. Kurva voltase $\mathrm{V}_{3}$ dibanding resistansi batuan dengan resistor pembagi $1 \mathrm{k} \Omega, 10 \mathrm{k} \Omega$, dan 100 $\mathrm{k} \Omega$.
Dari kurva pada Gambar 8 dan Tabel 1 diketahui bahwa nilai $R_{p}$ yang optimal adalah $100 \mathrm{k} \Omega$ karena pada saat mengukur min $V_{3}$ (resistivitas batuan terbesar) dan $\max V_{3}$ (resistivitas batuan terkecil) menghasilkan hasil yang cukup besar dibanding resolusi minimal ADC ADS1115 Arduino.

Tabel 1. Nilai maksimum dan minimum yang dapat diukur untuk resistor pembagi $1 \mathrm{k} \Omega, 10 \mathrm{k} \Omega$, dan $100 \mathrm{k} \Omega$.

\begin{tabular}{ccc}
\hline & \multicolumn{2}{c}{$\mathrm{V}_{3}(\mathrm{~V})$} \\
\cline { 2 - 3 } & $\operatorname{Min}$ & $\operatorname{Max}$ \\
\hline $10^{3}$ & 0.0002 & 0.656 \\
$10^{4}$ & 0.0026 & 2.650 \\
$10^{5}$ & 0.0260 & 3.806 \\
\hline
\end{tabular}

Mengacu pada Halliday dkk., 2011 listrik dialirkan dari permukaan sampel bukan menusuk batuan dengan elektroda. Sampel yang telah dipotong sedemikian rupa sehingga berbentuk silinder atau balok dihubungkan dengan plat tembaga di kedua ujung permukaan seperti Gambar 9.

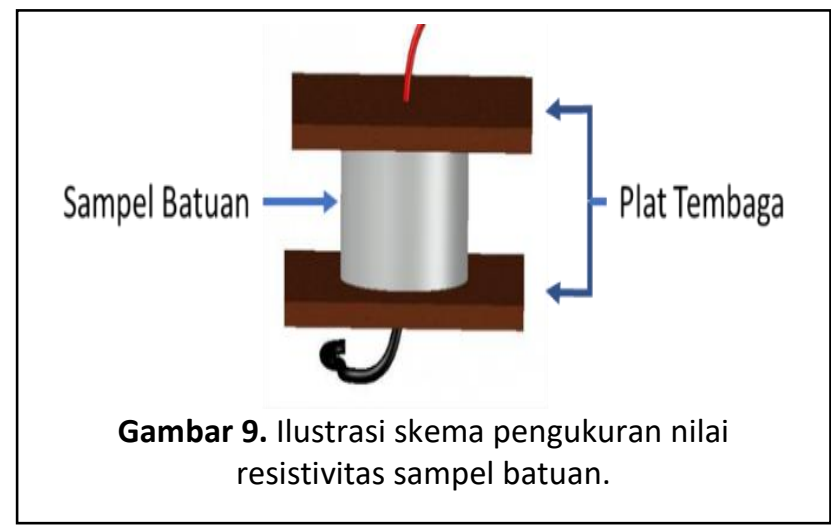

Untuk menahan agar pengukuran tetap stabil, model standar tersebut dikembagkan menjadi mekanik seperti Gambar 10. 


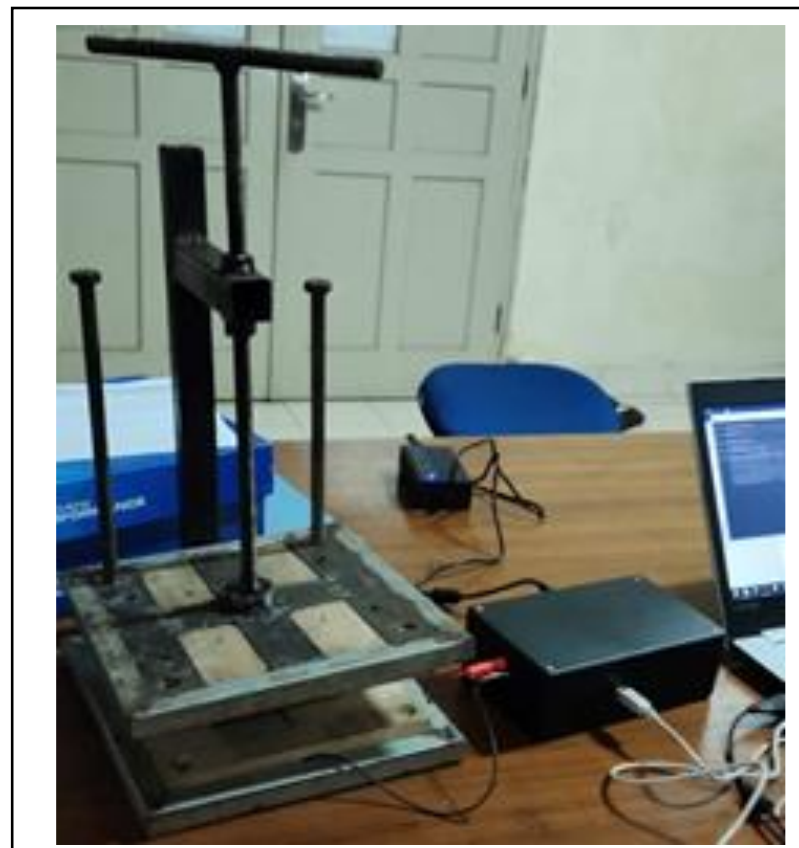

Gambar 10. Instrumen Real Time Rock Resistivity Meter, yang terdiri mekanik dan recording unit.

Pengukuran dilakukan dengan mengunakan rangkaian di bawah. Nilai tegangan $V_{3}$ diukur dengan analog to digital converter (ADC) yang memiliki kemampuan meresolusi hingga 15-bit, yaitu ADS1115. Data dari ADS1115 dikirim melalui Arduino ke komputer secara langsung (real time). Pada instrumen ini juga digunakan switch untuk membalik polarisasi listrik yang masuk ke sampel. Switch dikontrol langsung dengan komputer.

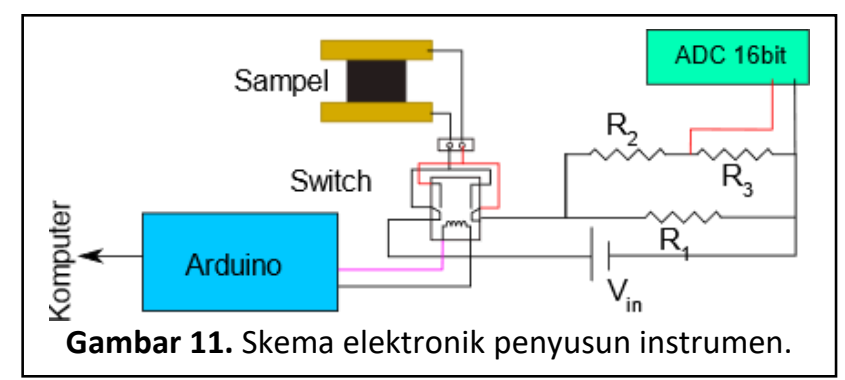

Pada Gambar 11, data yang direkam oleh Arduino dikirim ke perangkat komputer untuk dipantau dan direkam. Pemantauan dan perekaman dilakukan dengan sebuah program yang dibuat menggunakan bahasa pemrograman python. Hasil pengukuran disimpan ke dalam komputer dengan jenis file .csv. Program ini juga dapat digunakan untuk menampilkan dan menganalisis data yang

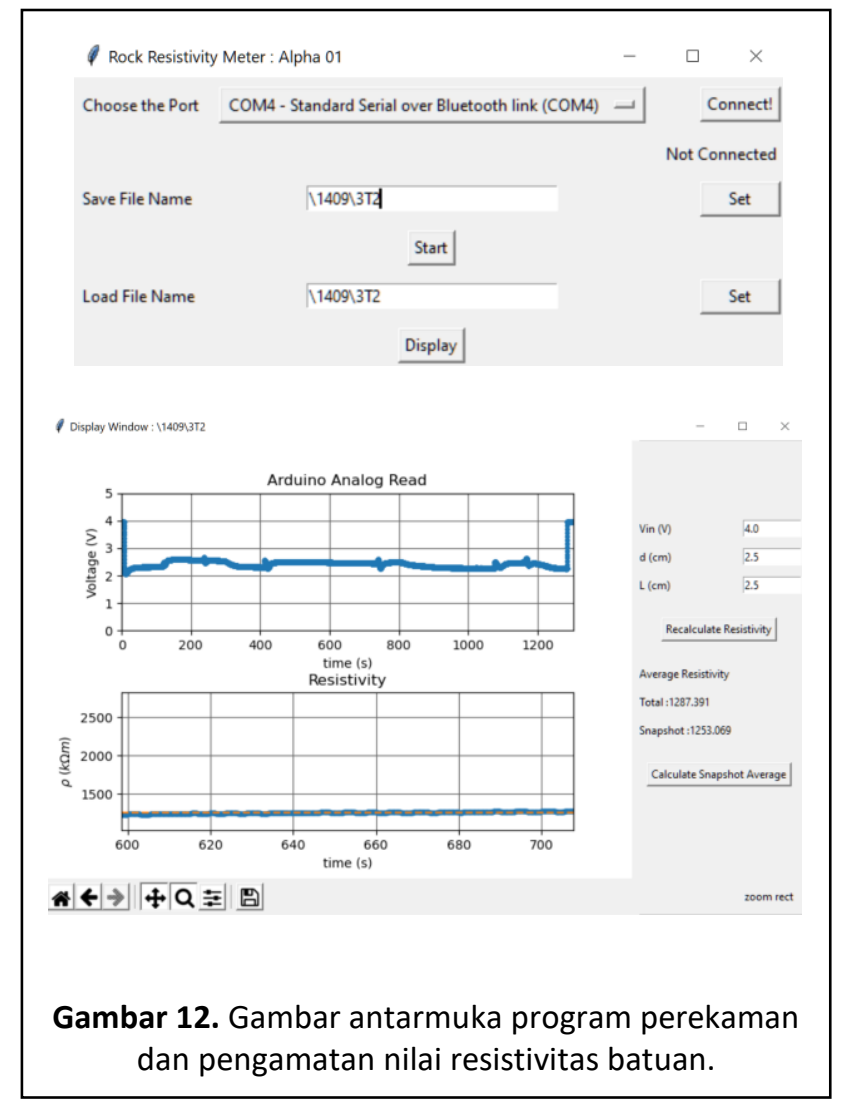

direkam. Berikut tampilan program antarmuka di sistem operasi Windows 10 . Program dapat menghitung nilai resistivitas sampel berdasarkan dimensi sampel (Gambar 12).

Sampel batuan yang keras diusahakan dibentuk dalam bentuk silider, sedangkan untuk batuan yang lunak dan mudah pecah bentuk yang digunakan adalah balok.

\section{HASIL DAN PEMBAHASAN}

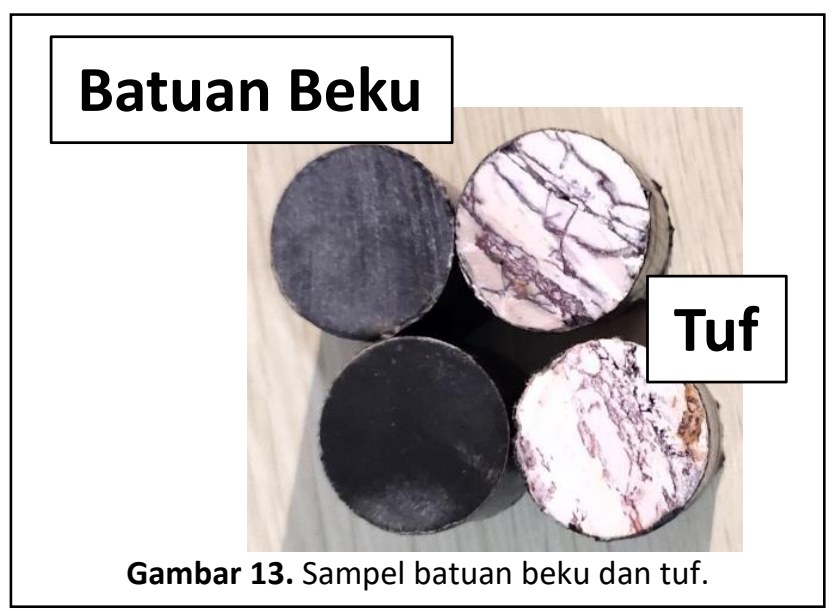

Untuk mengetahui performa dari alat yang digunakan, dilakukan uji dengan resistor $1 \mathrm{k} \Omega, 10 \mathrm{k} \Omega$ 
dan $100 \mathrm{k} \Omega$ dengan rentang kesalahan $\pm 1 \%$. Hasil uji resistor $1 \mathrm{k} \Omega$ adalah $1.003 \mathrm{k} \Omega$, sedangkan untuk resistor $10 \mathrm{k} \Omega$ adalah $10.07 \mathrm{k} \Omega$, dan $100 \mathrm{k} \Omega$ adalah $100.9 \mathrm{k} \Omega$ dan $1 \mathrm{M}$, toleransi $2 \%, 1021731.511$.

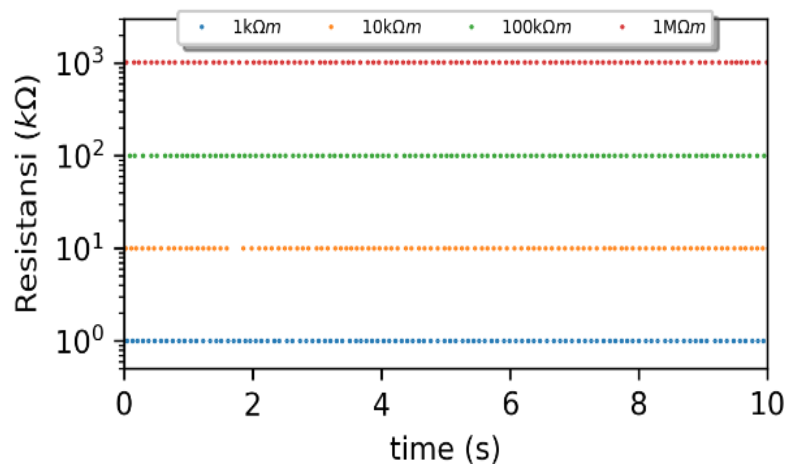

Gambar 14. Hasil pengukuran resistor $1 \mathrm{k} \Omega, 10 \mathrm{k} \Omega$, $100 \mathrm{k} \Omega$, dan $1 \mathrm{M} \Omega$.

Pengukuran dilakukan dengan waktu 10s, dengan rentang pengukuran $85 \mathrm{~ms}$ hingga $100 \mathrm{~ms}$. Total pengukuran selama 10 s adalah kurang lebih 100 data. Dari hasil tersebut didapatkan nilai berikut. Pada Tabel 2 tampak bahwa nilai yang terukur masih sesuai dengan nilai resistor dan lebih rendah dari error yang tertera pada resistor. Hal ini menunjukkan bahwa instrumen yang dibuat dapat secara tepat mengukur resistansi dan dapat diterapkan untuk mengukur resistivitas sampel batuan.

Tabel 2. Validasi instrumen Real Time Rock Resistivity Meter dengan mengukuran resistor.

\begin{tabular}{ccccc}
\hline $\begin{array}{c}\text { Resistor } \\
(\Omega)\end{array}$ & Error & $\begin{array}{c}\text { Rata-rata } \\
\text { Pengukuran } \\
(\Omega)\end{array}$ & $\begin{array}{c}\text { Eror } \\
\text { Pengukuran }\end{array}$ & $\begin{array}{c}\text { Std } \\
\text { dev }\end{array}$ \\
\hline 1000 & $1 \%$ & 1003 & $0.4 \%$ & 1.38 \\
10000 & $1 \%$ & 10073 & $0.7 \%$ & 1.56 \\
100000 & $1 \%$ & 100926 & $0.9 \%$ & 14.07 \\
1000000 & $2 \%$ & 1021735 & $2.2 \%$ & 157.89 \\
\hline
\end{tabular}

Selanjutnya adalah mengukur sampel batuan yang ada, yaitu batuan tuf. Batuan tuf yang digunakan adalah batuan tuf yang telah mengalami fase metamorfosa sehingga batuan tersebut menjadi lebih keras dan menjadi lebih padat. Selain menjadi lebih keras, di batuan tersebut muncul rekahan-rekahan.

Listrik dengan beda tegangan 80V diinjeksikan ke dalam sampel batuan tuf, dengan menggunakan instrumen Real Time Rock Resistivity Meter didapatkan pola tegangan dan resistivitas pada sampel sebagai berikut. Pada Gambar 15 tampak bahwa pola tegangan di sampel $\left(\mathrm{V}_{0}\right)$ naik dan berangsur konstan di akhir pengukuran. Sementara itu ketika dikonversi kedalam besaran resistivitas nilai resistvitas juga naik sebanding dengan kenaikan tegangan $\mathrm{V}_{0}$.

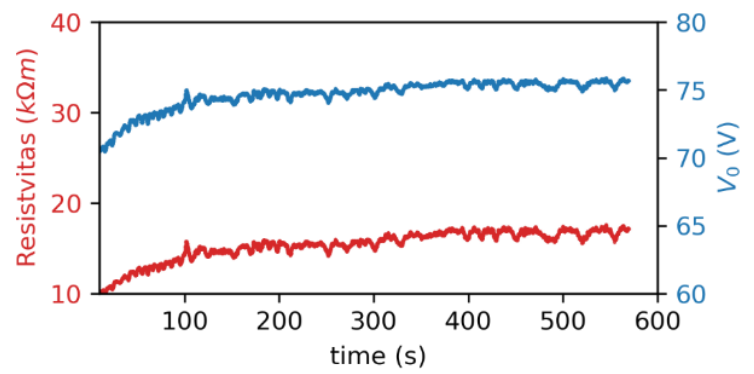

Gambar 15. Kurva rekaman tegangan dan resistivitas sampel batuan.

Untuk saat ini, kami mendefinisikan resistivitas batuan ketika nilai resistvitas yang terukur stabil, hal ini juga dilakukan ketika mengukur nilai resistivitas di lapangan dengan menggunakan alat geolistrik manual seperti Naniura.

Berikut ini adalah hasil pengukuran nilai resistivitas sampel tuf dengan posisi sampel yang berbeda. Posisi awal disebut sebagai polaritas positif, atau posisi pertama batuan ketika dialiri arus dan polaritas negative atau posisi setelah batuan itu dibalik dari posisi awal. Saat polaritas positif nilai resistivitas terukur sebesar $15,9 \mathrm{k} \Omega \mathrm{m}$. Sementara itu, ketika polaritas negative nilai resistivitas batuan beku yang terukur sebesar $11,1 \mathrm{k} \Omega \mathrm{m}$.

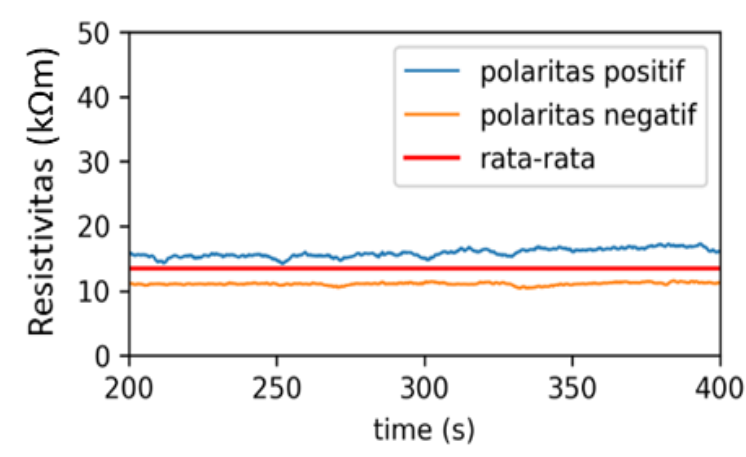

Gambar 16. Hasil rekaman polaritas positif dan polaritas negatif dari sampel batuan tuf, serta nilai rata-rata yang dipilih sebagai nilai resistivitas batuan tersebut. 
Hal ini diperkirakan karena adanya beda tegangan yang disimpan di dalam batuan. Oleh karena itu saat arus listrik searah dengan listrik yang tersipan maka nilai $\mathrm{V}_{0}$ yang terukur akan semakin besar dari nilai yang seharusnya, tapi akan berkurang jika arah terbalik. Seperti ilustrasi berikut

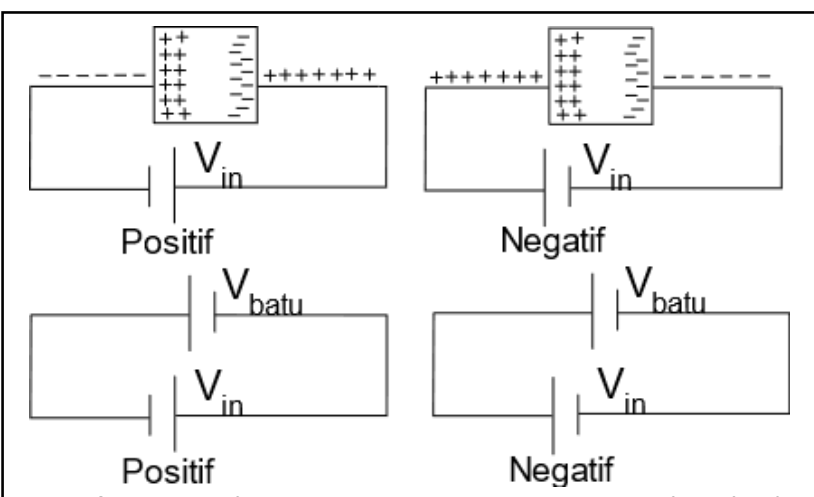

Gambar 17. Ilustrasi penyimpanan energi listrik di dalam batuan yang menyebabkan perbedaan nilai resistivitas batuan ketika polaritas positif dan negatif.

$$
\begin{array}{ll}
\text { Polaritas Positif } & V_{0}^{+}=V_{\text {in }}+V_{\text {batu }} \\
\text { Polaritas Negatif } & V_{0}^{-}=V_{\text {in }}-V_{\text {batu }} \\
& V_{0}=\left(V_{0}^{+}+V_{0}^{-}\right) / 2
\end{array}
$$

Dari data ini nilai resistivitas dapat dihitung dari rata-rata antara nilai polaritas positif dan negatif sehingga efek tegangan di dalam batuan dapat diminimalisir. Pada sampel batuan tuf, nilai ratarata kedua polarisasi adalah $12,6 \mathrm{k} \Omega \mathrm{m}$. Hal ini juga diterapkan pada pengukuran batuan beku, namun perbedaanya pada pengukuran nilai resistvitas batuan beku ditemukan adanya fluktuasi nilai yang teratur seperti pada gambar. Pola fluktuasi periodik ini muncul pada polaritas positif maupun negatif, tetapi rentang fluktuasi berbeda. Jika dirata-rata

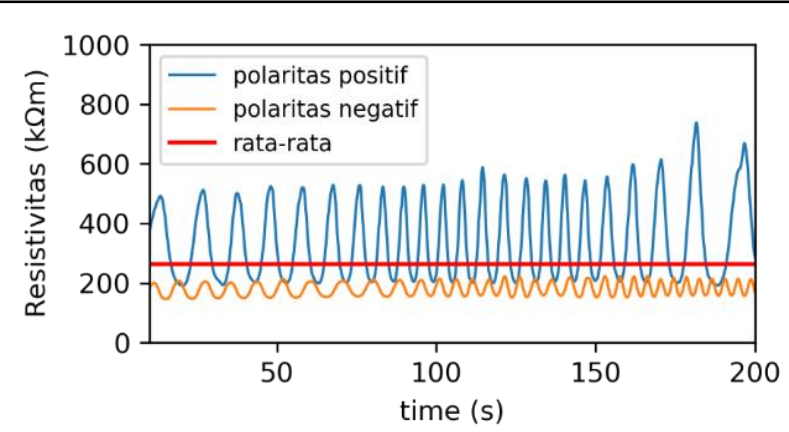

Gambar 18. Hasil rekaman polaritas positif dan polaritas negatif dari sampel batuan beku, serta nilai rata-rata yang dipilih sebagai nilai resistivitas batuan tersebut. maka nilai resistvitas pada polaritas positif dan negatif memiliki kencendrungan yang mirip dengan data sebelumnya yang mana nilai polarisasi positif dan negatif mencerminkan adanya beda tegangan yang tersimpan di dalam batuan. Proses merataratakan dapat menghilangkan efek tersebut. Nilai yang didapat dari pengukuran batuan beku adalah $262 \mathrm{k} \Omega \mathrm{m}$. Nilai ini masih masuk dalam rentang batuan beku pada Gambar 3.

Kami juga mencoba merendam sampel di dalam air untuk mengetahui efek air terhadap batuan. Sampel batuan direndam di dalam air selama 24 jam setinggi $20 \mathrm{~cm}$. Setelah itu diukur dan didapat hasil berikut. Batuan tuf memberikan perubahan nilai yang signifikan masih di dalam rentang pengukuran sebelum direndam di dalam
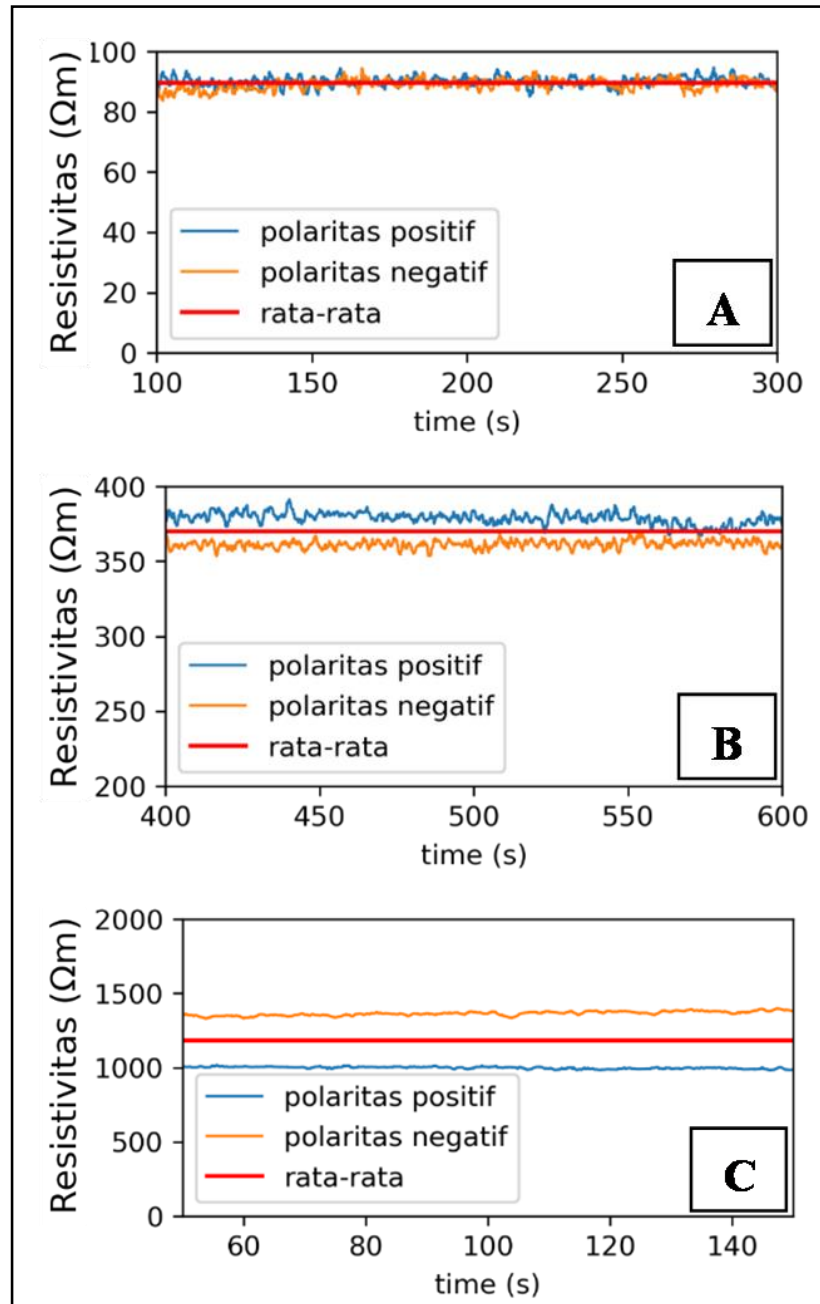

Gambar 19. Hasil rekaman polaritas positif dan polaritas negatif dari sampel batuan tuf a. 0 jam, b. 7,5 jam, c. 45 jam setelah direndam di dalam air setinggi $20 \mathrm{~cm}$. 
air, yaitu $89.6 \Omega \mathrm{m}$. Hasil pengukuran ini sangat rendah, dibanding pengukuran awal sebesar 12,6 $\mathrm{k} \Omega \mathrm{m}$. Penurunan ini dikarenakan air memiliki konduktifitas yang lebih baik sehingga nilai resistivitas batuan yang mengandung air akan lebih mudah menghantarkan listrik. Selain pengukuran nilai resisitivitas yang lebih rendah, perbedaan antara nilai polaritas positif dan negatif lebih kecil, yaitu $90,1 \Omega m$ untuk polaritas positif dan $89,1 \Omega m$ untuk polaritas negatif.

Nilai resistivitas tuf secara berangsur membesar sehingga dan juga perbedaan polaritas positif dan negatif makin besar juga (Gambar 19). Pada kasus ini terlihat bahwa semakin tinggi konten air di batuan maka nilai reisitivitas semakin rendah dan kemampuan batuan dalam menyimpan listrik semakin rendah. Ini dapat diakibatkan oleh adanya rekahan-rekahan di sampel yang menjadi tempat air mengisi. Porositas yang dibentuk oleh rekahan ini bisa berperan sebagai jalur mengalirnya air, sehingga jumlah air dengan cepat berkurang (Gambar 20) . Dengan perubahan ini otomatis nilai resistivitas akan naik.

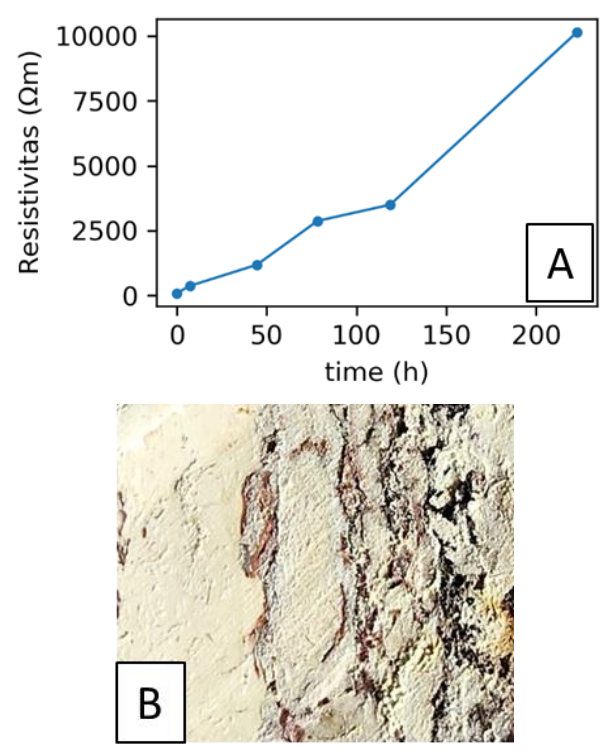

Gambar 20. a. Kurva nilai resistivitas batuan tuf dalam selang waktu 9 hari setelah direndam di dalam air sedalam $20 \mathrm{~cm}$. b. Gambar rekahan-rekahan di batuan tuf yang menyebabkan air dengan mudah mengisi dan keluar dari batuan.

\section{PENUTUP}

\section{Simpulan dan Saran}

Desain yang digunakan dalam pembuatan Real Time Rock Resistivity Meter ini adalah dengan menerapkan prinsip pembagi tegangan dan mekanisme pembalikan polaritas sumber listrik. Dari simulasi dan uji coba alat, dihasilkan sebuah instrumen Real Time Rock Resistivity Meter yang mampu menghitung nilai resistvitas. Hasil pengukuran alat ini divalidasi dengan mengukur resistor dengan resistansi $1 \mathrm{k} \Omega, 10 \mathrm{k} \Omega, 100 \mathrm{k} \Omega$, dan $1 \mathrm{M} \Omega$ dengan nilai error kurang dari $2.2 \%$.

Dengan menggunakan Real Time Rock Resistivity Meter dapat dibedakan nilai resistivitas batuan beku sebesar $262 \mathrm{k} \Omega \mathrm{m}$, batuan tuf sebesar $12,6 \mathrm{k} \Omega \mathrm{m}$. Batuan memiliki sifat menyimpan energi listrik, sehingga ketika diukur dengan polaritas yang berbeda nilai pengukuran resistivitas berbeda. Untuk itu dibuat sebuah mekanisme yang mampu meminimalisir pengaruh energi listrik yang tersimpan tersebut yaitu dengan membalik sumber listrik. Dari mekanisme yang diterapkan dipilih nilai rata-rata resistivitas. Selain itu, setelah direndam di dalam air batuan tuf menjadi lebih rendah. Di batuan tuf ditemukan banyaknya rekahan-rekahan yang bisa menyimpan air dan juga melewatkan air, oleh karena itu nilai resistivitas batuan tuf yang telah mengandung air akan berangsur membesar karena jumlah air yang berkurang melalui rekahan tersebut, sesuai dengan penelitian Lamur dkk., 2017. Dengan kemampuan ini, instrumen Real Time Rock Resistivity Meter dapat digunakan untuk validasi atau bahkan menghasilkan referensi nilai reisistivitas formasi batuan di sekitar kita.

Dari penelitian ini, hal yang perlu diteliti lebih lanjut adalah sifat kelistrikan batuan terhadap waktu, seperti pola periodik saat polaritas positif dan negatif. Selain itu, perlu didalami penyebab perbedaan nilai kapasitasi batuan untuk kondisi dan jenis batuan tertentu.

\section{Ucapan Terima Kasih}

Terima kasih kepada Lembaga Penelitian dan Pengabdian kepada Masyarakat (LPPM) Universitas Lampung yang telah mendanai penelitian ini melalui skema dana penelitian BLU Penelitian Dosen Pemula. 


\section{DAFTAR PUSTAKA}

Aluko, K. O., Raji, W. O., \& Ayolabi, E. A. (2017). Application of 2-D Resistivity Survey to Groundwater Aquifer Delineation in a sedimentary terrain: Application of 2-D resistivity survey to groundwater aquifer delineation in a sedimentary terrain: A case study of south-western Nigeria. Water Utility Journal, 17(May),

71-79. https://www.researchgate.net/publication/3250915 26

Caselle, C., Bonetto, S., \& Comina, C. (2019). Comparison of laboratory and field electrical resistivity measurements of a gypsum rock for mining prospection applications. International Journal of Mining Science and Technology. https://doi.org/10.1016/j.ijmst.2019.09.002

Dentith, M., \& Mudge, S. (2014). Geophysics for the mineral exploration geoscientist. In AusIMM Bulletin. https://doi.org/10.1017/cbo9781139024358

Giao, P. H., Chung, S. G., Kim, D. Y., \& Tanaka, H. (2003). Electric imaging and laboratory resistivity testing for geotechnical investigation of Pusan clay deposits. Journal of Applied Geophysics. https://doi.org/10.1016/S0926-9851(03)00002-8

Halliday, D., Resnick, R., \& Walker, J. (2011). Fundamentals of Physics 9th Edition. Fundamentals of physics.

Karyanto. (2007). Pendeteksian Penyebaran Limbah Cair Pada Media Padat dengan Metode Geolistrik Tahanan Jenis 3D. Jurnal Sains MIPA Unila, 13.

Lamur, A., Kendrick, J. E., Eggertsson, G. H., Wall, R. J., Ashworth, J. D., \& Lavallée, Y. (2017). The permeability of fractured rocks in pressurised volcanic and geothermal systems. Scientific Reports. https://doi.org/10.1038/s41598-017-05460-4

Mohammed, M. A., Senosy, M. M., \& Abudeif, A. M. (2019). Derivation of empirical relationships between geotechnical parameters and resistivity using electrical resistivity tomography (ERT) and borehole data at Sohag University site, upper Egypt. Journal of African Earth Sciences. https://doi.org/10.1016/j.jafrearsci.2019.103563

Raji, W. O., \& Adedoyin, A. D. (2020). Dam safety assessment using $2 \mathrm{D}$ electrical resistivity geophysical survey and geological mapping. Journal of King Saud University - Science, 32(1), 1123-1129. https://doi.org/10.1016/j.jksus.2019.10.016

Telford, W. M., Geldart, L. P., \& Sheriff, R. E. (1990). Applied Geophysics. In Cambridge University Press
(Second

Edi). 